\title{
The Reserpine Production and Callus Growth of Indian Snake Root (Rauvolfia serpentina (L.) Benth. Ex Kurz) Culture by Addition of $\mathrm{Cu}^{2+}$
}

\author{
NUNUNG NURCAHYANI, SOLICHATUN", ENDANG ANGGARWULAN \\ Biology Department, Faculty of Mathematics and Natural Science, Sebelas Maret University, Surakarta 57126.
}

Received: $29^{\text {th }}$ March 2008. Accepted: $12^{\text {th }}$ June 2008

\begin{abstract}
The objectives of this research were to study the effects of $\mathrm{Cu}^{2+}$ addition on the reserpine production and callus growth from in vitro culture indian snake root (Rauvolfia serpentina (L.) Benth. Ex Kurz). This research frame work was based on the potency of snake root which was many exploited as anti-hypertension. The addition of elicitor $\mathrm{Cu}^{2+}$ in the form of $\mathrm{CuCl}_{2}$ would influence the ion transport of cell and changed of cytoplasm $\mathrm{pH}$, and also has effects on synthesis and activity of enzymes which role in reserpine production and callus growth. The research was conducted in two steps, using Completely Randomized Design. The first step was the callus initiation to promote callus growth. Second step was the treatment to induce reserpine production. The callus was divided into five groups: $0 ; 5 ; 10 ; 20 ; 40 ;$ and $80 \mu \mathrm{M}$. Morphology, wet weight, dry weight, growth rate, and reserpine content of callus were determined after 15 treatment day. Data were analyzed using ANOVA and continued by DMRT $5 \%$. The result showed that reserpine production increased in addition of $5 \mu \mathrm{M}$ and $10 \mu \mathrm{M}$ $\mathrm{Cu}^{2+}$ in callus culture of $R$. serpentina and reduced in addition of $\mathrm{Cu}^{2+}$ more than $10 \mu \mathrm{M}$. The callus growth significantly decreased by increasing concentration of $\mathrm{Cu}^{2+}$.
\end{abstract}

@ 2008 Jurusan Biologi FMIPA UNS Surakarta

Key words: Rauvolfia serpentina, reserpine, elicitor, Cu2+, callus growth.

\section{INTRODUCTION}

Pule pandak or Indian snake root (Rauvolfia serpentine (L.) Benth. ex Kurz) has been used medically since 2000 BC. The plant extract and alkaloids are used mostly in treating high blood pressure, sedative, aphrodisiac, and mental disorders (Ramawat, 1999). A number of alkaloids as reserpine, reserpinin, serpentine, ajmalin, and isoajmalin could be produced from this plant. Reserpine was used to cure the high blood pressure or hypertension and its complications, stroke, and the diseases related with nervous system (Achmad, 1987).

In this time, pule pandak in Indonesia included in groups of plant were endangered (Mulliken and Crofton, 2008). Requirement of raw material of pule pandak for the jamu industry and pharmacy progressively mount, whereas most raw material (more than $80 \%$ ) still have to be harvested from natural habitat (Supriyadi, 2001). To get pule pandak in high amounts of secondary metabolites, the plants have to reach the certain age (years), so that exploitation from nature can menace its species, and also difficult to be done (Ramawat, 1999). Therefore require an effort to be able to lessen the pressure to population of pule pandak in nature; at the same time fulfill the request of compound reserpine in gross. This matter can be gone through with the technique of culture in vitro.

Some technique of in vitro culture has been used to improve the accumulation of secondary metabolites, one of

\footnotetext{
- Corresponding address:

JI. Ir. Sutami 36A Surakarta 57126

Tel.: +62-271-663375 Fax.: +62-271-663375

E-mail: solichatun_s@yahoo.com
}

them called elicitation technique. Elicitation technique is process of elicitor addition at plant culture to induce or improve the product of secondary metabolites. Elicitors could be biotic or abiotic factors. Numerous investigations have reported that addition of abiotic elicitor including $\mathrm{Cu}^{2+}$ increased alkaloid production. Sato et al. (1997) reporting $\mathrm{Cu}^{2+}$ remarkable enhanced both the growth and the alkaloid yield in hairy root cultures of Hyoscyamus albus. Existence $\mathrm{Cu}^{2+}$ at plant can also influence the transport ion from and to cytoplasm and competitively displacement of $\mathrm{Ca}^{2+}$ from the membrane biding site (Polle and Schutzendubel, 2002). Addition of a component that able to pursue the internal and external transportation $\mathrm{Ca}^{2+}$ reported can induce the accumulation and production of the indol alkaloid at hairy root culture of Catharanthus roseus (Valenzuela et al., 2003). $\mathrm{Cu}^{2+}$ at $5 \mu \mathrm{M}$ caused a $50 \%$ block in $\mathrm{Ca}^{2+}$ transportation (Demidchik et al., 1997). Ions $\mathrm{Cu}^{2+}$ that is tied at protein can improve transportation of electron in photosynthesis and respiration and also improve the activity of enzyme catalyze (Gardner et al., 1991).

\section{MATERIAL AND METHODS}

The research was conducted in two steps. The first was the callus initiation to promote callus growth. The second was the treatment of elicitor addition to induce the reserpine production on callus culture.

\section{Plant tissue culture}

Young leaves (second or third leaf from sprout) of $R$. serpentine were collected from Tekil mount, Wonogiri. Leaves were surface sterilized for $10 \mathrm{~min}$ in liquid 
detergent, soaked in $45 \%$ sodium hypochlorite (5.25\%), 10 min in sterile aquadest, $5 \mathrm{~min}$ in $70 \%$ ethanol and then they were washed two times with sterile aquadest in laminar air flow hood.

The callus induction media was composed of MS (Murashige and Skoog) basal medium and supplemented with $30 \mathrm{~g} / \mathrm{L}$ sucrose, NAA $2 \mathrm{mg} / \mathrm{L}$, and kinetin $2 \mathrm{mg} / \mathrm{L}$. After growing for 30 day, the callus were elicited with $0 \mu \mathrm{M}, 5 \mu \mathrm{M}$, $10 \mu \mathrm{M}, 20 \mu \mathrm{M}, 40 \mu \mathrm{M}$, and $80 \mu \mathrm{M} \mathrm{Cu}{ }^{2+}$ as $\mathrm{CuCl}_{2}$ in basal medium without added $\mathrm{NH}_{4} \mathrm{NO}_{3}$ and $\mathrm{NAA}$, the amount of $\mathrm{KH}_{2} \mathrm{PO}_{4}$ reduced to $100 \mathrm{mg} / \mathrm{L}$, and supplemented with 80 $\mathrm{g} / \mathrm{L}$ sucrose and kinetin $5 \mathrm{mg} / \mathrm{L}$ (Aryanti, 2005).

Cultures were harvested on day 15 of subculture in a treatment medium. The dry weight of callus was determined after drying the sample at $38^{\circ} \mathrm{C}$ to constant weight. Dried callus were crushed to a fine powder with a mortar and pestle. Approximately $0.1 \mathrm{~g}$ of dried callus was placed in a tube react and extracted with $10 \mathrm{~mL}$ ethanol p.a. and diluted to the volume with double-distilled water in a $100 \mathrm{~mL}$ standard flask. To each this tube was added with $1 \mathrm{~mL}$ of freshly prepared $0.3 \%(\mathrm{w} / \mathrm{v})$ solution of sodium nitrite, then mixed and heated in a water bath at $55^{\circ} \mathrm{C}$ for $30 \mathrm{~min}$. After cooling, $0.5 \mathrm{~mL}$ of freshly prepared solution of sulfamic acid $5 \%(\mathrm{w} / \mathrm{v})$ was added and diluted up to the mark with ethanol. The absorbance of solution was measured at 399 $\mathrm{nm}$ against a reagent blank by using spectrophotometer of UV-VIS Shimadzu (Singh et al., 2004 with modification).

Data were analyzed statistically by analysis of variance (ANOVA) followed by DMRT 5\%. Data of callus morphology covering color and texture presented descriptively.

\section{RESULT AND DISCUSSION}

\section{Culture growth}

The explants were incubated on basal MS media with addition $2 \mathrm{mg} / \mathrm{L} \mathrm{NAA}$ and $2 \mathrm{mg} / \mathrm{L}$ kinetin demonstrated callus formation after 7 days incubation. Explants formed callus at the cut surface and its color is white chromatic lay. Shared explants which initiation to form callus caused by a cell which contact with the medium incited to become meristematic and here in after perform the division tissues of wound cover. Its have been explained by Santoso and Nursandi (2002) whereas callus formed as attempt of plant protection as a result of the stress or expression of wound.

Callus color at initiation medium changed from white to

Table 1. The accumulation of dry weight (DW) of callus cultures in treatment media. The data shown are the means of five replicates experiments. Means labeled with identical letters are not significantly different at $95 \%$ of confidence level.

\begin{tabular}{ccccccc}
\hline & \multicolumn{7}{c}{$\mathrm{Cu}^{2+}$ concentration $(\mu \mathrm{M})$} \\
\hline $\begin{array}{c}\text { Dry weight of } \\
\text { callus }(\mathrm{g})\end{array}$ & $\mathrm{Cu}_{0}$ & $\mathrm{Cu}_{1}$ & $\mathrm{Cu}_{2}$ & $\mathrm{Cu}_{3}$ & $\mathrm{Cu}_{4}$ & $\mathrm{Cu}_{5}$ \\
\cline { 2 - 7 } & $0,2690^{\mathrm{d}}$ & $0,2302^{\mathrm{cd}}$ & $0,2182^{\mathrm{bc}}$ & $0,2134^{\mathrm{abc}}$ & $0,1814^{\mathrm{ab}}$ & $0,1748^{\mathrm{a}}$ \\
\hline
\end{tabular}

Cu: concentration of $\mathrm{CuCl}_{2}$. $\mathrm{Cu}_{0}: 0 \mu \mathrm{M} ; \mathrm{Cu}_{1}: 5 \mu \mathrm{M} ; \mathrm{Cu}_{2}: 10 \mu \mathrm{M} ; \mathrm{Cu}_{3}: 20 \mu \mathrm{M} ; \mathrm{Cu}_{4}: 40 \mu \mathrm{M}$; and $\mathrm{Cu}_{5}: 80 \mu \mathrm{M}$.

Table 2. The reserpine production of callus cultures in treatment media. The data shown are the means of five replicates experiments. Means labeled with identical letters are not significantly different at the $95 \%$ of confidence level.

\begin{tabular}{ccccccc}
\hline \multicolumn{8}{c}{$\mathrm{Cu}^{2+}$ concentration $(\mu \mathrm{M})$} \\
\hline $\begin{array}{c}\text { Reserpine } \\
\text { production }(\mathbf{m g} / \mathbf{g})\end{array}$ & $0,6226^{\text {ab }}$ & $0,8786^{\mathrm{a}}$ & $0,8351^{\mathrm{a}}$ & $0,6238^{\mathrm{ab}}$ & $0,6678^{\mathrm{ab}}$ & $0,3712^{\mathrm{b}}$ \\
\hline
\end{tabular}
Cu: concentration of $\mathrm{CuCl}_{2}$. $\mathrm{Cu}_{0}: 0 \mu \mathrm{M} ; \mathrm{Cu}_{1}: 5 \mu \mathrm{M} ; \mathrm{Cu}_{2}: 10 \mu \mathrm{M} ; \mathrm{Cu}_{3}: 20 \mu \mathrm{M} ; \mathrm{Cu}_{4}: 40 \mu \mathrm{M}$; and $\mathrm{Cu}_{5}: 80 \mu \mathrm{M}$. become yellow greenness until young green color. Existence of light can enhance chlorophyll production. solid cell and difficult to be dissociated. Callus texture at initiation medium that is compact until the end of treatment periods (Tables 1). The high of kinetin concentration at (5 mg/L) caused the compact callus. Kinetin in high concentration can enhanced cell division and ormed the compact callus.

Rauvolfia serpentina callus which elicited by addition of $u^{2+}$ did not change the callus color to brown (browning) compared by color of control callus. This is possibility caused by height of concentration of kinetin in medium. concentration were known as an antioxidant agent. Antioxidant were used in medium also enhanced the chlorophyll biosynthesis at callus cells.

Callus with $\mathrm{Cu}^{2+}$ at 10-80 $\mathrm{M}$ had significantly lower of dry weight than control (Table 1$). \mathrm{Cu}^{2+}$ required by callus cell in a small amount. $\mathrm{Cu}^{2+}$ at high levels becomes strongly phytotoxic cell and causes inhibition of plant growth or even cell death (Wang et al., 2004). The inhibition of dry weight (DW) accumulation in callus suggested that copper (Cu) excess result in membrane damage and ion $\mathrm{K}^{+}$leakage. Potassium plays an important role in vacuole where it contributes largely to the osmotic pressure and thus to the turgor pressure. Cell which lost of turgor pressure leaded to in cell elongation (Alaoui-Sosse et al., 2004). Potassium also plays to activate the enzyme which is element will be accumulation of carbohydrate and decreased of starch rate, so that cause inhibition on photosynthesis (Salisbury and Ross, 1995; Alaoui-Sosse et al., 2004). Inhibition of resistance photosynthesis process will cause the callus growth become pursued and also aller dry weight yielded.

and $\mathrm{Ca}$; so that the higher absorption of another ions (Srivastava and Gupta, 1996). Calcium (Ca) include of essential macro element in cell growth, that is to function of ion $\mathrm{Ca}^{2+}$ forming $\mathrm{Ca}$-pektat as leasing of cell wall and also existence of ion $\mathrm{Ca}^{2+}$ in early anaphase follow the initiative process the division of mitosis cell phase especially anaphase (Reksoatmojo, 1993). Addition of $\mathrm{Cu}^{2+}$ abundant in media caused the absorption of $\mathrm{Ca}^{2+}$ decreased and influenced the division of cell culture.

$\mathrm{Fe}$ and $\mathrm{Mg}$ elements play important role in chlorophyll forming. $\mathrm{Fe}$ influenced the concentration of glycine and succinil-CoA forming $\partial$-amino laevulinat acid (Srivastava and Gupta, 1996), while $\mathrm{Mg}$ assist the forming proto-porfirin become proto-chlorofilid (Salisbury and Ross, 1995). Prassad (1998) reported that heavy metal can pursue chlorophyll forming by pursuing activity of $\partial$-amino laevulinat and protochlorofilid reductase. This is caused the degradation of amount of photosynthesis pigment which finally will influence the callus growth.

\section{Reserpine production}

Reserpine production increased in $\mathrm{Cu}^{2+}$ concentration of $5 \mu \mathrm{M}$ added in 
callus culture of pule pandak (Table 2.). The addition of $\mathrm{Cu}^{2+}$ as a biotic elicitor in medium will cause $\mathrm{H}^{+}$-ATP-ase inactivation (Hall, 2002; Demidchik et al., 1991) and degradation of $\mathrm{pH}$ cytoplasm. The cytoplasm acidity will induce enzyme synthesis needed in reserpine biosynthesis. According to Hagendoorn et al. (1996) whereas the addition of elicitor will influence the transport of ion $\mathrm{H}^{+}$pass the cell membrane and will influence the degradation of $\mathrm{pH}$ cytoplasm. This condition will induce activation of enzymes which playing apart in secondary metabolism synthesis.

Reactive oxygen species (ROS) production increased as a response to $\mathrm{Cu}^{2+}$ metal ion stress; this is also suggested have an effect on reserpine accumulation. According to Mithofer et al. (2004) which explained that ROS are involved in the oxidation of polyunsaturated fatty acids (PUFA) to PUFA hydro-peroxide (PUFA-OOH), which are converted to oxylipin. Jasmonat represent one of linolenic acid-derived oxylipins. Synthesis and accumulation of methyl jasmonat (Me-JA) during elicitor addition plays important role to induce the defense gene and also improve the arrangement of secondary metabolites synthesis. VomEndt et al. (2002) reported that the Me-JA accumulation resulted in over expression Str biosynthesis gene (strictosidin synthase) and increased in TIA (terpenoid indole alkaloid) production. Reserpine as main secondary metabolites collected from pule pandak includes in terpenoid indole alkaloid compounds.

Callus with $\mathrm{Cu}^{2+}$ at $80 \mu \mathrm{M}$ had lower reserpine production than control. This result suggested excess of $\mathrm{Cu}^{2+}$ elicitor in the concentration caused plasma membrane leakage so that reserpine in cell secrete into the surrounding culture medium. Mentioned by Sevon and Oksman-Caldentey (2002) those biotic and abiotic elicitors were able to release the product of secondary metabolites from hairy culture into medium without any loss of viability and production capacity of the hairy roots.

\section{CONCLUSION}

The addition of elicitor $\mathrm{Cu}^{2+}$ at $5 \mu \mathrm{M}$ enhanced the reserpine production, while addition above $10 \mu \mathrm{M}$ decreased the reserpine production of callus culture of Rauvolfia serpentina. Callus growth significantly decreased with addition of $\mathrm{Cu}^{2+}$ elicitor in MS medium.

\section{REFERENCES}

Achmad, S.A. 1987. Metabolit sekunder: suatu kerangka untuk memahami potensi sumber daya alam nabati Indonesia. Dalam: Pramono, S., D. Gunawan, dan C.J. Soegihardjo. (ed.). Buku Risalah Seminar Nasional Metabolit Sekunder. Yogyakarta: PAU Bioteknologi UGM.

Alaoui-Sosse, B. P. Genet, F. Vinit-Dunad, T. Marei-Laure, D. Epron, and P.M. Badot. 2004. Effect of copper on growth in cucumber plants
(Cucumis sativus) and its relationships with carbohydrate accumulation and changes in ion contents. Plant Science 30:1-6.

Armini, N.M., G.A. Wattimena, dan L.W. Gunawan. 1992. Perbanyakan tanaman. Dalam: Wattimena, G.A. (ed.). Bioteknologi Tanaman. Tim Laboratorium Kultur Jaringan Tanaman. Bogor: PAU Bioteknologi.

Demidchik, V., A. Sokolik, and V. Yurin. 1997. The effect of $\mathrm{Cu}^{2+}$ on ion transport systems of the plant cell plasmalemma. Plant Physiology 144: 1313-1325.

Gardner, F.P., R.B. Pearce, and R.L. Mitchell. 1991. Fisiologi tanaman Budidaya. Penerjemah: Susilo, H. Jakarta: UI Press.

Hagendoorn, A.W. L.H.W. van der Plas, and H.S. van Wal-Raver, 1996. Petunia hybrida: in vitro cultures and the production of antocyanin and other secondary metabolites. In: Bajaj, Y.P.S. Biotechnology in Agricultural and Forestry, Medical and Aromatic Plants IX. 37:284-300. New York: Springer-Verlag

Hall, J.L. 2002. Review article: Cellular mechanism for heavy metal detoxification and tolerance. Journal of Experimental Botany 53 (366): 111.

Lemenager, D., M. Clastre, M. Rideau, and J. Aguirreolea. 2004. Hormone Mediated Alkaloids Accumulation: Implication of Redox State in Cytokinin Signalling? Tours: Universite Francois.

Mithofer, A., B. Schulze, and W. Boland. 2004. Hypothesis biotic and heavy metal stress in plants: evidence for common signals. FEBS Letters 566: $1-5$.

Mulabagal, V. and H.-S. Tsay. 2004. Plant cell culture: an alternative and efficient source for the production of biologically important secondary metabolism. International Journal of Applied Science of England. 291: 29-48

Mulliken ,T. and P. Crofton, 2008. Review of the Status, Harvest, Trade and Management of Seven Asian CITES-listed Medicinal and Aromatic Plant Species. Federal Agency for Nature Conservation. Bonn, Germany. $p$ 93-112

Polle, A and A. Schutzendubel. 2002. Plant responses to abiotic stresses: heavy metal induced oxidative stress and protection by mycorrhization. Journal of Experimental Botany 53 (372): 1351-1365.

Prassad, M.N.V. 1998. Metal-biomolecules complexes in plants: occurrence functions and application. Analysis Magazine 26: 25-28.

Ramawat, K.G. 1999. Production in culture: optimization. In: Ramawat, K.G. and J.M. Merillon. (eds.) Biotechnology Secondary Metabolites. New Hampshire: Science Publishers, Inc.

Ramawat, K.G. and K.C. Sonie. 1999. Production under stress In: Ramawat, K.G. and J.M. Merillon. (eds.) Biotechnology Secondary Metabolites. New Hampshire: Science Publishers, Inc.

Reksoatmojo, I. 1993. Biologi Sel. Yogyakarta: UGM Press

Salisbury, F.B. dan C.W. Ross. 1995. Fisiologi Tumbuhan. Penerjemah: Padmawinata, K. Bandung: Penerbit ITB.

Santoso, U. dan F. Nursandi. 2002. Kultur Jaringan Tanaman. Malang: UMM Press

Sato, K., H. Kubota, Y. Goda, T. Yamada, and T. Maitani. 1997. Glutathione enhanced anthraquinone production in adventitious root cultures of Rubia tinctorum L. Plant Biotechnology 14 (1): 63-66.

Sevon, N. and K.M. Oksman-Caldentey. 2002. Agrobacterium rhizogenesmediated transfornation: root cultures as source of alkaloids. Planta Medica 68: 859-868.

Singh, D.V., B. Srivastava, and A Sahu. 2004. Spectrophotometric determination of Rauwolfia alkaloids: estimation of reserpine in pharmaceutical. Analytical Science 20: 571-573.

Srivastava, P.C. and U.C. Gupta. 1996. Trace Elements in Crop Production. New Delhi: Science Publishers Inc.

Supriyadi. 2001. Tumbuhan Obat Indonesia: Penggunaan dan Khasiatnya. Edisi I. Jakarta: Pustaka Populer Obor.

Valenzuela, O.A.M. Y.M. Garcia, E.M. Geraldo, and V.M. Vargar. 2003. Increase in the indole alkaloids production and its excretion into the culture medium by calcium antagonists in hairy roots. Biotechnology Letters 25 (16): 1345-1349

Vom-Endt, D., J.W. Kijne, and J. Memelink. 2002. Transcription factors controlling plant secondary metabolism: what regulates the regulators? Phytochemistry 61: 107-114.

Wang, S.-H., Z.-M. Yang, H. Yang, B. Lu, S.-Q. Li, and Y.-P. Lu. 2004. Copper-induced stress and antioxidative responses in roots of Brassica juncea L. Botanical Bulletin of Academia Sinica 45: 203-212. 